\title{
Istraživanje zadovoljstva posjetitelja zaštićenih područja Istarske županije
}



1 Suzana Marković

1 Sveučilište u Rijeci, Fakultet za menadžment u turizmu i ugostiteljstvu, Opatija, Hrvatska

\section{Sažetak}

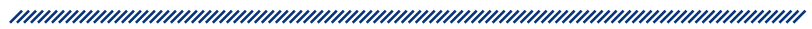

Uvod: Zaštićena područja prirode predstavljaju krhke oaze povezanosti čovjeka s prirodom u njezinu izvornom obliku u kojima je glavni cilj zaštita biološke, geološke i krajobrazne raznolikosti. Zbog sve većeg socioekonomskog razvoja, s povećanjem industrijalizacije, prometa te urbanizacije održivi turizam i briga za očuvanje prirode tek sinergijskim djelovanjem mogu umanjiti težnje za profitom kroz prekomjernu izgrađenost i posjećenost koja može negativno djelovati na zaštićeno područje (degradacija staništa, onečišćenje i sl.) i time dovesti u pitanje osnovnu svrhu postojanja.

Cilj ovog rada bio je istražiti i analizirati stavove posjetitelja zaštićenih područja Istarske županije o kvaliteti usluge, analizirati njihovo zadovoljstvo i lojalnost, očekivanja i percepciju, te izračunati ECOSERV jaz. U tu svrhu izvršena je prilagodba ljestvice mjerenja ECOSERV (Khan 2003). Upitnik se sastoji od pet dimenzija (eko-opipljivost, povjerenje, pouzdanost, poistovjećivanje, susretljivost, opipljivost) i 29 tvrdnji te pitanja koja se odnose na sociodemografski profil ispitanika (dob, spol, obrazovanje, zanimanje, razlog dolaska, broj posjeta).

Uzorak i metode: Istraživanje je provedeno na uzorku od 137 posjetitelja u sljedećim zaštićenim područjima: Nacionalni park Brijuni, Park prirode Učka, park-šuma Šijana i Kamenjak. U istraživanju su sudjelovali samo domaći posjetitelji.

Rezultati: Rezultati deskriptivne statističke analize pokazali su da postoji jaz između očekivane i percipirane kvalitete usluga, što znači da ustanove nisu ispunile očekivanja svojih posjetitelja, iako su posjetitelji ocijenili kvalitetu usluga u parkovima prirode visokom prosječnom ocjenom.

Ključne riječi: zadovoljstvo posjetitelja, kvaliteta usluga, ECOSERV, zaštićena područja prirode, statistička analiza

Datum primitka: 5.6.2019.

Datum prihvaćanja: 1.9.2019.

DOI: $10.24141 / 1 / 5 / 2 / 12$

Adresa za dopisivanje:

Prof. dr. sc. Suzana Marković

A: Sveučilište u Rijeci, Fakultet za menadžment u turizmu i ugostiteljstvu, Opatija, Hrvatska

E-mail: suzanam@fthm.hr

T: +385992455901 


\section{Uvod}



ekološki turizam ili ekoturizam u Hrvatskoj ima veliki potencijal zbog relativno netaknute prirode i očuvane kulturne baštine te predstavlja priliku za veću raznolikost turističke ponude uz društveno odgovorno poslovanje. Razvoj ekoturizma utemeljen je na prirodnim resursima destinacije. Stoga ekološka osviještenost nije samo trend, već pokazuje konstantan rast broja ekoturista kojima je zaštita okoliša i prirode važna kroz doživljaj, odnosno upoznavanje tradicije i kulture destinacije.

Stoga je cilj ovog rada bio prikazati rezultate pregleda dosadašnje strane i domaće literature o istraživanju i mjerenju kvalitete usluga u nacionalnim parkovima i parkovima prirode primjenom modela SERVQUAL i ECOSERV te rezultate statističke analize stavova posjetitelja u parkovima prirode. $U$ tu svrhu izvršeno je ispitivanje stavova posjetitelja o kvaliteti usluga, zadovoljstvu, lojalnosti te su ispitana njihova očekivanja i percepcija.

Rezultati analize prikazani su u nastavku ovog rada.

\section{Teorijski okvir}

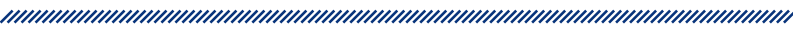

U teorijskom dijelu rada opisat će se koncept kvalitete usluga i zadovoljstva, model SERVQUAL i ostali modeli koji su primijenjeni u istraživanju stavova posjetitelja nacionalnih parkova ili parkova prirode.

\section{Kvaliteta usluga i zadovoljstvo klijenta}

Kvaliteta usluga i zadovoljstvo klijenta dva su koncepta kojima je posvećena velika pozornost $u$ istraživanjima slobodnog vremena, rekreacije i turizma te u novije vrijeme ekoturizma (Lee i sur. 2004; O’Neill i sur. 2010; Rivera i Croes 2010). Kvaliteta usluga i zadovoljstvo klijenta su usko povezani koncepti, vrlo kompleksni i isprepleteni, koji se odnose na cjelokupni aspekt subjektivnog prosuđivanja korisnika (Sureshchandar i sur. 2002).

Kvaliteta usluga apstraktan je, višedimenzionalan, promjenjiv koncept koji je teško definirati, opisati i izmjeriti (Marković 2003). Prema Grönroosovu modelu (1984), kvaliteta predstavlja opći sud ili stav prema usluzi koji proizlazi iz usporedbe očekivanja i percepcije korisnika o performansama aktualne usluge. Ostrowski i sur. (1993) smatraju da je kvaliteta usluge način razmišljanja kako udovoljiti kupcima (npr. posjetiteljima zaštićenih područja) da bi se zadovoljilo njihovo poimanje kvalitete. MacKay i Crompton (1990) pri definiranju kvalitete usluge smatraju da je najvažniji odnos između želja potrošača (posjetitelja) i njegove percepcije dobivenog (npr. obilaska i boravka u zaštićenom području). Percepcije kvaliteta usluga važne su u ekoturizmu (ali i šire) zbog njihova utjecaja na zadovoljstvo te direktnog i indirektnog utjecaja na lojalnost (Lee i sur. 2004; TianCole i Crompton 2003; Tian-Cole i sur. 2002; Zabkar i sur. 2010).

Neki autori, poput Cronina i Taylora (1992) te Gotlieba i sur. (1994), smatraju kako je upravo kvaliteta usluge prethodila zadovoljstvu klijenta. Parasuraman i suradnici (1988) smatraju kako je zadovoljstvo emocionalna reakcija korisnika koja se javlja kada neka usluga ili proizvod premaši njihova očekivanja. Zadovoljstvo, kao psihološki rezultat ili emocionalni odgovor (Crompton i Love 1995; Manning 2011), znatno je manje podložno upravljanju. Također, može biti pod utjecajem faktora koji su izvan kontrole menadžera kao npr. posjetiteljevo raspoloženje, emocije ili čak vremenski uvjeti (Lee i sur. 2004; Tian-Cole i sur. 2002). Prema Oliveru (1981), zadovoljstvo korisnika javlja se nakon usluge koju je korisnik dobio, nakon što ju je usporedio sa svojim očekivanjima, koja su u ovom slučaju bila u potpunosti ispunjena, što je na kraju rezultiralo zadovoljstvom. Oliver (1981) naglašava kako korisnici na temelju svojih očekivanja o pruženoj usluzi ocjenjuju njezinu kvalitetu. Napominje kako će korisnici čija su očekivanja bila premašena ocijeniti kvalitetu usluge visokom, dok će korisnici koji nisu bili zadovoljni pruženim uslugama, tj. imali su veća očekivanja, kvalitetu smatrati niskom.

Kvaliteta usluga i zadovoljstvo slični su, ali ipak različiti koncepti. Općenito, zadovoljstvo predstavlja mjeru emocionalnog stanja posjetitelja nakon posjeta destinacije, dok je kvaliteta usluga zapravo percepcija kvalitete performansi temeljena na ocjeni usluga (npr. interakcija osoblja s posjetiteljima) i ustanova (npr. infrastruktura) (Parasauraman 1985; Tian-Cole i sur. 2002; Tian-Cole i Crompton 2003; Žabkar i sur. 2010). Liljander i Strandvik (1995) postavili su model kvalitete odnosa koji se bazira na promatranju transakcija između pružatelja usluga i korisnika (koncept zadovoljstva korisnika). Naglasak je modela na analizi procesa koji se događaju između korisnika i uslužnog poduzeća te stupnju povezanosti tih činitelja. Glavna je pretpostavka ovog mo- 
dela povezanost između kvalitete usluge i zadovoljstva korisnika. Autori naglašavaju da zadovoljstvo/nezadovoljstvo korisnika može isključivo nastati interakcijom između subjekta i objekta u proizvodno-uslužnom procesu te da kvalitetu pružene usluge korisnici mogu spoznati bez obzira na proces usluživanja. S obzirom na ovu razliku, očito je da menadžeri zaštićenih područja vjerojatno imaju veću kontrolu nad kvalitetom usluga nego nad zadovoljstvom.

\section{Mjerenje kvalitete usluga}

Parasuraman i sur. (1985) naglašavaju kako se kvaliteta usluga može definirati i kao zadovoljstvo korisnika koji nastaje iz jaza između očekivanja korisnika i njihove percepcije. Jaz između očekivane i percipirane usluge najvažniji je prilikom analiziranja kvalitete pruženih usluga. Njime se otkriva kolika je razina zadovoljstva ili nezadovoljstva korisnika. Formula za izračunavanje jaza: Q = P - E, gdje je Q - kvaliteta usluge (engl. service quality), $\mathrm{P}$ - percepcije korisnika usluge (engl. perceptions), E - očekivanja korisnika usluge (engl. expectations). Na temelju ovog izračuna, što je veći rezultat oduzimanja „percepcije” od „očekivanja”, veća je i percipirana kvaliteta usluge (Ladhari 2009.)

Na temelju takvog koncepta (Parasuraman i sur. 1988; 1998) razvijen je alat za mjerenje kvalitete usluga, tzv. model SERVQUAL koji je primjenjiv u svim uslužnim djelatnostima, pa tako i pri zaštiti prirode zbog svoje unificiranosti i dimenzija kvalitete koje se ispituju. Model SERVQUAL u svojem početku obuhvaćao je deset dimenzija koje su kasnije objedinjene u pet dimenzija: pouzdanost, sigurnost, opipljivost, susretljivost i poistovjećivanje (Parasuraman i sur. 1985). Za potrebe istraživanja očekivanja kvalitete usluga, i to primarno posjetitelja zaštićenog područja (ekoturista) (Khan 2003), razvijena je prilagođena verzija ljestvice mjerenja SERVQUAL pod nazivom ECOSERV, koja se sastoji od šest dimenzija; eko-opipljivost (engl. eco-tangibles), povjerenje (engl. assurance), pouzdanost (engl. reliability), poistovjećivanje (engl. responsiveness), susretljivost (engl. empathy) i opipljivost (engl. tangibles).

Analizom svjetske i domaće literature iz područja kvalitete usluga i zadovoljstva klijenata u zaštićenim područjima može se zaključiti kako većina istraživača primjenjuje vlastite mjerne instrumente. Model SERVQUAL ili ECOSERV kojim se ispituju očekivanja i percepcije posjetitelja zaštićenih područja te njihovo zadovoljstvo na području zaštićenih područja u Hrvatskoj se primjenjuje vrlo rijetko. Prvo sveobuhvatno istraživanje o sta- vovima posjetitelja nacionalnih parkova i parkova prirode u Hrvatskoj provedeno je 2006. godine (Marušić i Tomljanović 2006) u šest nacionalnih parkova (Plitvička jezera, Krka, Sjeverni Velebit, Paklenica, Brijuni i Kornati) i dva parka prirode (Kopački rit i Biokovo) na slučajnom uzorku od 2258 ispitanika, a obuhvaćalo je sociodemografske podatke ispitanika, motivaciju dolaska, način na koji su doznali za destinaciju, prosječnu potrošnju i sl. Kosović (2006) je proveo istraživanje strukture upravljanja, organizacije rada i analize poslovanja u suradnji s upravom park-šume Marjan, grad Split. Krpina (2015) je proveo istraživanje na području Nacionalnog parka Paklenica, Parka prirode Telašćica i Parka prirode Vransko jezero, u kojem su na uzorku od 720 ispitanika istraženi stavovi posjetitelja, njihovi zahtjevi, motivacija za dolazak te zadovoljstvo kvalitetom usluga i turističke ponude u zaštićenim područjima prirode.

Na području zaštićenih područja u Istri dosad nisu bila provođena slična istraživanja te je ovo istraživanje doprinos u razumijevanju tog problema i može poslužiti kao osnova za unaprjeđenje upravljanja zaštićenim područjima u Istri.

Unatoč mnogobrojnim istraživanjima, mjerenje zadovoljstva posjetitelja zaštićenih područja (nacionalnih parkova, parkova prirode, rezervata) nije dovoljno istraženo. Model za mjerenje kvalitete usluga SERVQUAL pokazao se pouzdanim i valjanim u različitim relevantnim svjetskim znanstvenim istraživanjima. U skladu s time, smatra se opravdanom primjena modificiranog SERVQUAL-a namijenjenog istraživanju zadovoljstva posjetitelja na području ekoturizma nazvanog ECOSERV.

\section{Rezultati empirijskog istraživanja}

\section{Ciljevi istraživanja}

Ciljevi empirijskog istraživanja bili su: (a) analizirati stavove posjetitelja zaštićenih područja o kvaliteti usluga, (b) analizirati zadovoljstvo i lojalnost posjetitelja, (c) analizirati očekivanja i percepcije posjetitelja te (d) izračunati ECOSERV jaz (percepcija - očekivanje).

U skladu s postavljenim ciljevima istraživanja, postavljena je i glavna hipoteza istraživanja koja glasi: Primjenom modela ECOSERV moguće je procijeniti razinu zadovoljstva posjetitelja zaštićenih područja Istre. 


\section{Upitnik i prikupljanje podataka}

Ispitivanje zadovoljstva posjetitelja zaštićenih područja Istarske županije provedeno je primjenom prilagođenog modela ECOSERV (Khan 2003) za mjerenje zadovoljstva posjetitelja. Od travnja do listopada 2017. godine izvršeno je ispitivanje posjetitelja četiriju zaštićenih područja u Istarskoj županiji: Nacionalnog parka Brijuni, Parka prirode Učka, zaštićenog krajobraza Kamenjak te parkšume Šijana. Anketni upitnik sastojao se od četiri dijela. Prvi dio upitnika sastoji se od 29 tvrdnji koje se odnose na očekivanja posjetitelja zaštićenih područja Istarske županije o kvaliteti pruženih usluga. Ispitanici su ocjenjivali kvalitetu usluge s pomoću Likertove ljestvice od sedam stupnjeva u kojoj broj 1 znači „u potpunosti se ne slažem”, dok broj 7 znači „u potpunosti se slažem”. Tvrdnje su preuzete i prilagođene prema ljestvici ECOSERV (Khan 2003). Drugi dio anketnog upitnika sastojao se od 29 tvrdnji koje se odnose na percepciju posjetitelja. Treći dio anketnog upitnika ispitivao je zadovoljstvo i lojalnost uz pomoć sljedećih tvrdnji: ,Zadovoljan/ zadovoljna sam sveukupnom ponudom i uslugom zaštićenog područja”, „Ponovno bih posjetio/posjetila ovo zaštićeno područje”, „Preporučio/preporučila bih ovo zaštićeno područje drugima." U posljednjem dijelu anketnog upitnika nalaze se tvrdnje uz pomoć kojih je analiziran sociodemografski profil ispitanika: dob, spol, obrazovanje, zanimanje, razlog dolaska, broj posjeta ovog ili nekog drugog zaštićenog područja.

Od ukupno 200 distribuiranih anketnih upitnika na hrvatskom jeziku ispravno je bilo popunjeno 137 ili $68,5 \%$. U istraživanju su sudjelovali samo domaći posjetitelji.

\section{Rezultati statističke analize}

Tablica 1 prikazuje sociodemografski profil ispitanika te rezultate statističke analize percepcije, očekivanja i lojalnosti ispitanika.

Na temelju podataka iz tablice 1 može se zaključiti kako najveći dio ispitanika čine mladi ispitanici do 35 godina s udjelom od $70,81 \%$. Ispitanici srednje dobi od 36 do 55 godina u uzorku su zastupljeni s $25,55 \%$, dok ispitanici od 56 i više godina čine svega 3,63 \% ispitanih. $U$ uzorku prevladavaju osobe ženskog spola s udjelom od $54,1 \%$, dok su osobe muškog spola bile zastupljene u nešto manjem broju (46 \%). Većinu ispitanika (52,55 \%) činile su zaposlene osobe, zatim učenici i studenti $(40,15 \%)$, dok je najmanje bilo nezaposlenih ispitanika $(5,84 \%)$ i umirovljenika (1,46 \%). Analizirajući stupanj obrazovanja ispitanika može se zaključiti da najveći udio čine ispitanici s visokim obrazovanjem te ispitanici

\begin{tabular}{|c|c|c|}
\hline \multirow{2}{*}{$\begin{array}{c}\text { Karakteristike } \\
\text { ispitanika }\end{array}$} & \multicolumn{2}{|c|}{ Frekvencije } \\
\hline & APSOLUTNE & RELATIVNE (\%) \\
\hline \multicolumn{3}{|c|}{ Dob } \\
\hline $16-25$ & 64 & 46,72 \\
\hline $26-35$ & 33 & 24,09 \\
\hline $36-45$ & 24 & 17,52 \\
\hline $46-55$ & 11 & 8,03 \\
\hline $56-65$ & 3 & 2,19 \\
\hline 66 i više & 2 & 1,46 \\
\hline \multicolumn{3}{|c|}{ Spol } \\
\hline Muški & 63 & 45,99 \\
\hline Ženski & 74 & 54,01 \\
\hline \multicolumn{3}{|c|}{ Zanimanje } \\
\hline Zaposlen & 72 & 52,55 \\
\hline Nezaposlen & 8 & 5,84 \\
\hline Učenik/student & 55 & 40,15 \\
\hline Umirovljenik & 2 & 1,46 \\
\hline \multicolumn{3}{|c|}{ Obrazovanje } \\
\hline Osnovna škola & 4 & 2,92 \\
\hline Srednja škola & 52 & 37,96 \\
\hline $\begin{array}{l}\text { Viša škola ili } \\
\text { fakultet }\end{array}$ & 79 & 57,66 \\
\hline Ostalo & 2 & 1,46 \\
\hline \multicolumn{3}{|c|}{ Motiv dolaska } \\
\hline $\begin{array}{l}\text { Znanstveno- } \\
\text { istraživačke svrhe }\end{array}$ & 5 & 3,65 \\
\hline Obrazovne svrhe & 9 & 6,57 \\
\hline $\begin{array}{l}\text { Odmor i } \\
\text { opuštanje }\end{array}$ & 64 & 46,72 \\
\hline Rekreacija i sport & 33 & 24,09 \\
\hline $\begin{array}{l}\text { Ljubitelji prirode i } \\
\text { kulturne baštine }\end{array}$ & 13 & 9,49 \\
\hline Ljepota krajolika & 10 & 7,30 \\
\hline Ostalo & 3 & 2,19 \\
\hline \multicolumn{3}{|c|}{ Broj posjeta } \\
\hline Prvi put & 23 & 16,79 \\
\hline Dva puta & 15 & 10,95 \\
\hline Više od dva puta & 92 & 67,15 \\
\hline Ostalo & 7 & 5,11 \\
\hline \multicolumn{3}{|c|}{ Posjećenost više zaštićenih područja Istre } \\
\hline $\mathrm{Da}$ & 90 & 65,69 \\
\hline $\mathrm{Ne}$ & 47 & 34,31 \\
\hline
\end{tabular}


sa srednjom i osnovnom školom (40,8 \%). Najčešći motiv dolaska u posjet zaštićenom području bilo je u svrhu odmora u prirodi i opuštanja (46,72\%), rekreacije i sporta $(24,09 \%)$ te ostalih razloga ( $29 \%)$. Čak $67 \%$ ispitanika posjetilo je zaštićeno područje više od dva puta, $16 \%$ ispitanika prvi put, $10 \%$ dva puta te $5 \%$ ostalo (ispitanici koji rade na zaštićenom području). Većina ispitanika (65\%) posjetila je više zaštićenih područja na području Istarske županije.

Primjenom prilagođenog modela ECOSERV za mjerenje kvalitete usluga analizirana su očekivanja posjetitelja i njihova percepcija nakon posjeta zaštićenog područja te je izračunan ECOSERV jaz (tablica 2).

Na temelju podataka iz tablice 2 može se zaključiti kako su posjetitelji imali relativno visoka očekivanja uzevši u obzir prosječnu ocjenu od 6,04. Međutim, prosječna ocjena percepcije kvalitete usluga nešto je niža te iznosi 4,99. Prema tome je izračunan ukupan ECOSERV jaz ( $P$ - O) te iznosi -1,05 (tablica 4). Vidljivo je kako izračunani jaz ima negativne vrijednosti kod svih tvrdnji (tablica 4), što govori o tome kako je percipirana usluga niža od očekivane te se može zaključiti kako ni u jednom segmentu nisu premašena očekivanja posjetitelja.

Dimenzija „eko-opipljivost” sastoji se od tri varijable $(1-3)$ i ujedno je najvažnija dimenzija jer se primjenjuje isključivo u istraživanjima ekoturizma. Tvrdnjama unutar ove dimenzije ispituje se jesu li ustanove, oprema, pokretni i nepokretni objekti u zaštićenom području u skladu s održivim razvojem i okolišem (da su ekološki prihvatljivi i da ne degradiraju okoliš).

U tablici 3 prikazane su prosječne ocijene prema dimenzijama na ljestvici očekivanja i ljestvici percepcije te je izračunan ukupni ECOSERV jaz.

Dimenzija „eko-opipljivost” imala je najmanju prosječnu ocjenu i najveći negativan jaz, što je čini najlošije ocijenjenom dimenzijom, što znači da su potrebne promjene ovog aspekta ponude. Dimenzija „povjerenje” sastoji se od četiri varijable $(4-8)$ kojima se ispituje znanje i ljubaznost zaposlenog osoblja (edukatori, voditelji, čuvari prirode) te sposobnost pružanja svih potrebnih informacija. Dimenzija „pouzdanost” sastoji se od četiri varijable $(9-13)$ i ispituje je li usluga realizirana pravodobno, odgovorno i točno. Dimenzija „poistovjećivanje" uključuje tri varijable $(14-17)$ i odnosi se na spremnost ustanove/osoblja da pruža pravodobnu i brzu uslugu te s ocjenom od 5,28 predstavlja najbolje ocijenjenu dimenziju. Dimenzija ,susretljivost” uključuje pet varijabli $(18-22)$ te ispituje brigu i individualiziranu pažnju koju ustanova pruža svojim posjetiteljima, dok se dimenzija „opipljivost” sastoji od šest varijabli (23 - 29) kojima se ispituje kvaliteta objekata, opreme i materijala, koji su odraz lokalne kulture.

U tablicama 4 i 5 prikazane su tvrdnje s najvišom prosječnom ocjenom (tablica 4) te tvrdnje s najnižom prosječnom ocjenom (tablica 5).

$\mathrm{Na}$ ljestvici očekivanja tvrdnja „Objekti u zaštićenom području moraju biti u skladu su s okolišem" ocijenjena je najvišom ocjenom $(6,70)$. Ova varijabla spada u dimenziju ekološke opipljivosti. Slijede je tvrdnje iz dimenzije povjerenja: „Djelatnici zaštićenog područja moraju imati dovoljno znanja i iskustva da uspješno odgovaraju na sva pitanja posjetitelja” (6,53), „Infrastruktura zaštićenog područja mora biti prilagođena divljim vrstama koje obitavaju na zaštićenom području" $(6,49)$, „Zaštićeno područje mora voditi računa o zbrinjavanju otpada" $(6,48)$. Na posljednjem mjestu nalazi se tvrdnja iz dimenzije opipljivosti: „Djelatnici zaštićenog područja moraju imati odgovarajuću uniformu (biti prepoznatljivi posjetiteljima)" (6,44).

$\mathrm{Na}$ ljestvici percepcije najvišom prosječnom ocjenom ocijenjena je tvrdnja „Djelatnici zaštićenog područja uvijek su spremni pomoći” $(5,46)$. Slijede dvije tvrdnje iz dimenzije pouzdanosti: „Djelatnici zaštićenog područja ponašaju se ljubazno prema posjetiteljima" $(5,41)$, „Djelatnici zaštićenog područja pružaju usluge u predviđenom vremenu (edukacija - vrijeme polaska, staza; odlazak na manje izlete i sl.)" (5,31). Na četvrtom i petom mjestu nalaze se tvrdnje iz dimenzije poistovjećivanja: „Djelatnici zaštićenog područja pružaju ispravnu uslugu iz prvog pokušaja” (5,30), „Djelatnici zaštićenog područja pokazuju interes u rješavanju problema (npr. ozljeda posjetitelja, napadaj alergije i sl.)" $(5,27)$.

$\mathrm{Na}$ ljestvici očekivanja najmanjom ocjenom $(4,59)$ ocijenjena je tvrdnja „Djelatnici zaštićenog područja moraju pružati posjetiteljima individualiziranu uslugu", što je bilo i očekivano s obzirom na to da su uglavnom posjetitelji dolazili u skupinama, a ne individualno. Slijede je tvrdnje „Djelatnici zaštićenog područja moraju pružati posjetiteljima osobnu pažnju” (5,23), „Djelatnici zaštićenog područja moraju uvažavati specifične potrebe posjetitelja (akrofobija, klaustrofobija, alergije i sl.)” $(5,45)$, „Djelatnici zaštićenog područja moraju moći informirati posjetitelje o tome kada će usluga točno biti pružena” $(5,53)$ te „Objekti u zaštićenom području (smještajni kapaciteti, restorani, suvenirnice...) moraju biti vizualno atraktivni" $(5,61)$.

$\mathrm{Na}$ ljestvici percepcije najmanju ocjenu $(4,17)$ dobila je tvrdnja „Objekti i oprema u zaštićenom području ekološ- 


\section{Tablica 2. Rezultati deskriptivne statističke analize ( $\mathbf{N}=137)$}

\begin{tabular}{|c|c|c|c|c|}
\hline R. br. & Dimenzije i varijable & $\mathrm{O}$ & $\mathrm{P}$ & ECOSERV jaz \\
\hline & EKO-OPIPLJIVOST (engl. ECO-TANGIBLES) & & & \\
\hline 1 & Objekti u zaštićenom području moraju biti u skladu s okolišem. & 6,70 & 5,00 & $-1,70$ \\
\hline 2 & $\begin{array}{c}\text { Infrastruktura (putovi, ceste, znakovi...) u zaštićenom području ne smije utjecati na } \\
\text { degradaciju okoliša. }\end{array}$ & 5,95 & 4,61 & $-1,34$ \\
\hline \multirow[t]{2}{*}{3} & $\begin{array}{l}\text { Objekti i oprema u zaštićenom području moraju biti ekološki prihvatljivi, bez znatnog utjecaja } \\
\text { na okoliš (vozila na struju, korištenje obnovljivim izvorima energije, recikliranje otpada...). }\end{array}$ & 6,31 & 4,17 & $-2,15$ \\
\hline & POVJERENJE (engl. ASSURANCE) & & & \\
\hline 4 & Zaštićeno područje mora voditi računa o zbrinjavanju otpada. & 6,48 & 4,96 & $-1,52$ \\
\hline 5 & $\begin{array}{c}\text { Infrastruktura zaštićenog područja mora biti prilagođena divljim vrstama koje obitavaju } \\
\text { na zaštićenom području. }\end{array}$ & 6,49 & 5,00 & $-1,49$ \\
\hline 6 & Prilikom transakcije djelatnici zaštićenog područja moraju ulijevati povjerenje. & 6,30 & 5,02 & $-1,28$ \\
\hline 7 & Djelatnici zaštićenog područja moraju pružati pravodobne informacije (upozorenja i sl.). & 6,42 & 5,06 & $-1,36$ \\
\hline \multirow[t]{2}{*}{8} & $\begin{array}{c}\text { Djelatnici zaštićenog područja moraju imati dovoljno znanja i iskustva da uspješno } \\
\text { odgovaraju na sva pitanja posjetitelja. }\end{array}$ & 6,53 & 5,07 & $-1,47$ \\
\hline & POUZDANOST (engl. RELIABILITY) & & & \\
\hline 9 & Djelatnici zaštićenog područja moraju ulijevaju povjerenje posjetiteljima. & 6,37 & 5,26 & $-1,11$ \\
\hline 10 & Djelatnici zaštićenog područja moraju se ponašati ljubazno prema posjetiteljima. & 6,42 & 5,41 & $-1,01$ \\
\hline 11 & $\begin{array}{c}\text { Djelatnici zaštićenog područja moraju pružati usluge u predviđenom vremenu (edukacija } \\
\text { - vrijeme polaska, staza; odlazak na manje izlete i sl.). }\end{array}$ & 6,28 & 5,31 & $-0,96$ \\
\hline 12 & $\begin{array}{c}\text { Djelatnici zaštićenog područja moraju obavljati usluge unutar obećanog vremena (npr. } \\
\text { trajanje edukacije je tri sata). }\end{array}$ & 5,95 & 5,23 & $-0,72$ \\
\hline \multirow[t]{2}{*}{13} & Djelatnici zaštićenog područja moraju nastojati pružiti besprijekornu uslugu. & 6,04 & 5,12 & $-0,91$ \\
\hline & POISTOVJEĆIVANJE (engl. RESPONSIVENESS) & & & \\
\hline 14 & Djelatnici zaštićenog područja moraju pružati ispravnu uslugu iz prvog pokušaja. & 5,74 & 5,30 & $-0,44$ \\
\hline 15 & $\begin{array}{l}\text { Djelatnici zaštićenog područja moraju pokazivati interes u rješavanju problema (npr. } \\
\text { ozljeda posjetitelja, napadaj alergije i sl.). }\end{array}$ & 6,17 & 5,27 & $-0,90$ \\
\hline 16 & Djelatnici zaštićenog područja moraju biti uvijek spremni pomoći. & 6,17 & 5,46 & $-0,71$ \\
\hline \multirow[t]{2}{*}{17} & Djelatnici zaštićenog područja moraju pružati brzu uslugu posjetiteljima. & 6,01 & 5,11 & $-0,91$ \\
\hline & SUSRETLJIVOST (engl. EMPATHY) & & & \\
\hline 18 & $\begin{array}{l}\text { Djelatnici zaštićenog područja moraju biti uvijek na raspolaganju posjetiteljima } \\
\text { (posjetiteljima dati podatke za kontakt u slučaju nužde i sl.). }\end{array}$ & 5,61 & 4,88 & $-0,73$ \\
\hline 19 & $\begin{array}{l}\text { Djelatnici zaštićenog područja moraju moći informirati posjetitelje o tome kada će usluga } \\
\text { točno biti pružena. }\end{array}$ & 5,53 & 4,71 & $-0,82$ \\
\hline 20 & Djelatnici zaštićenog područja moraju pružati posjetiteljima osobnu pažnju. & 5,23 & 4,62 & $-0,61$ \\
\hline 21 & Djelatnici zaštićenog područja moraju pružati posjetiteljima individualiziranu uslugu. & 4,95 & 4,45 & $-0,50$ \\
\hline \multirow[t]{2}{*}{22} & Zaštićeno područje mora imati prilagođeno vrijeme za posjetitelje. & 5,85 & 5,20 & $-0,64$ \\
\hline & OPIPLJIVOST (engl. TANGIBLES) & & & \\
\hline 23 & $\begin{array}{l}\text { Djelatnici zaštićenog područja moraju uvažavati specifične potrebe posjetitelja } \\
\text { (akrofobija, klaustrofobija, alergije i sl.). }\end{array}$ & 5,45 & 4,82 & $-0,63$ \\
\hline 24 & $\begin{array}{l}\text { Djelatnici zaštićenog područja moraju uvažiti individualne interese posjetitelja (npr. } \\
\text { ljubitelje orhideja uputit će ili ih sami odvesti na mjesto na kojem mogu vidjeti veliki broj } \\
\text { vrsta orhideja). }\end{array}$ & 5,80 & 4,99 & $-0,82$ \\
\hline 25 & $\begin{array}{c}\text { Uređenje zaštićenog područja (pješačke staze, poučne ploče i sl.) mora biti odraz } \\
\text { lokalnog utjecaja. }\end{array}$ & 6,20 & 5,08 & $-1,12$ \\
\hline 26 & $\begin{array}{l}\text { Zaštićeno područje treba nuditi različite zabavne programe i društvene aktivnosti } \\
\text { (ekoakcije). }\end{array}$ & 5,94 & 4,96 & $-0,99$ \\
\hline 27 & $\begin{array}{l}\text { Promotivni materijali zaštićenog područja moraju biti vizualno atraktivni (fotografije, } \\
\text { opisi, karte npr. biciklističkih staza i sl.). }\end{array}$ & 6,28 & 5,00 & $-1,28$ \\
\hline 28 & $\begin{array}{c}\text { Objekti u zaštićenom području (smještajni kapaciteti, restorani, suvenirnice...) moraju } \\
\text { biti vizualno atraktivni. }\end{array}$ & 5,61 & 4,59 & $-1,02$ \\
\hline 29 & $\begin{array}{c}\text { Djelatnici zaštićenog područja moraju imati odgovarajuću uniformu (biti prepoznatljivi } \\
\text { posjetiteljima). }\end{array}$ & 6,44 & 5,15 & $-1,29$ \\
\hline AS & & 6,04 & 4,99 & $-1,05$ \\
\hline
\end{tabular}




\section{Tablica 3. Rezultati deskriptivne statističke analize prema dimenzijama ( $\mathbf{N}=137)$}

\begin{tabular}{|c|c|c|c|}
\hline Dimenzije & $\begin{array}{c}\text { OČEKIVANJE } \\
\text { Prosječna ocjena }\end{array}$ & $\begin{array}{c}\text { PERCEPCIJA } \\
\text { Prosječna ocjena }\end{array}$ & ECOSERV jaz \\
\hline Eko-opipljivost (engl. eco-tangibles) & 6,32 & 4,59 & $-1,73$ \\
\hline Povjerenje (engl. assurance) & 6,44 & 5,02 & $-1,42$ \\
\hline Pouzdanost (engl. reliability) & 6,21 & 5,26 & $-0,94$ \\
\hline Poistovjećivanje (engl. responsiveness) & 6,02 & 5,28 & $-0,74$ \\
\hline Susretljivost (engl. empathy) & 5,43 & 4,77 & $-1,02$ \\
\hline Opipljivost (engl. tangibles) & 5,97 & 4,94 & $-1,05$ \\
\hline Izvor: Izrada autora & 6,07 & 4,99 & \\
\hline
\end{tabular}

Tablica 4. Tvrdnje na ljestvici očekivanja i na ljestvici percepcije s najvišom prosječnom ocjenom $(\mathbf{N}=137)$

\begin{tabular}{|c|c|c|}
\hline \multicolumn{3}{|c|}{ Najviše prosječne ocijene } \\
\hline \multicolumn{3}{|c|}{ OČEKIVANJA } \\
\hline R. br. & Tvrdnja & AS \\
\hline 1 & Objekti u zaštićenom području moraju biti u skladu su s okolišem. & 6,70 \\
\hline 8 & $\begin{array}{c}\text { Djelatnici zaštićenog područja moraju imati dovoljno znanja i iskustva da uspješno odgovaraju na sva pitanja } \\
\text { posjetitelja. }\end{array}$ & 6,53 \\
\hline 5 & $\begin{array}{c}\text { Infrastruktura zaštićenog područja mora biti prilagođena divljim vrstama koje obitavaju na zaštićenom } \\
\text { području. }\end{array}$ & 6,49 \\
\hline 4 & Zaštićeno područje mora voditi računa o zbrinjavanju otpada. & 6,48 \\
\hline 29 & Djelatnici zaštićenog područja moraju imati odgovarajuću uniformu (biti prepoznatljivi posjetiteljima). & 6,44 \\
\hline \multicolumn{3}{|c|}{ PERCEPCIJA } \\
\hline R. br. & Tvrdnja & AS \\
\hline 16 & Djelatnici zaštićenog područja uvijek su spremni pomoći. & 5,46 \\
\hline 10 & Djelatnici zaštićenog područja ponašaju se ljubazno prema posjetiteljima. & 5,41 \\
\hline 11 & $\begin{array}{l}\text { Djelatnici zaštićenog područja pružaju usluge u predviđenom vremenu (edukacija - vrijeme polaska, staza; } \\
\text { odlazak na manje izlete i sl.). }\end{array}$ & 5,31 \\
\hline 14 & Djelatnici zaštićenog područja pružaju ispravnu uslugu iz prvog pokušaja. & 5,30 \\
\hline 15 & $\begin{array}{c}\text { Djelatnici zaštićenog područja pokazuju interes u rješavanju problema (npr. ozljeda posjetitelja, napadaj } \\
\text { alergije i sl.). }\end{array}$ & 5,27 \\
\hline
\end{tabular}

ki su prihvatljivi, nemaju znatan utjecaj na okoliš (vozila na struju, korištenje obnovljivim izvorima energije, recikliranje otpada...)", što jasno sugerira upravi i voditeljima zaštićenih područja koji je segment ponude najlošiji te im pruža izravnu mogućnost unaprjeđenja kvalitete usluga promjenom tog segmenta (eko-opipljivost). Slijede tvrdnje: „Djelatnici zaštićenog područja pružaju posjetiteljima individualiziranu uslugu” (4,45), „Objekti u zaštićenom području (smještajni kapaciteti, restorani, suvenirnice...) vizualno su atraktivni” (4,59), ,Infrastruktura (putovi, ceste, znakovi...) u zaštićenom području ne utječe na degradaciju okoliša” $(4,61)$ te „Djelatnici zaštićenog područja pružaju posjetiteljima osobnu pažnju" $(4,62)$. Važno je također naglasiti da tri od pet tvrdnji iz ljestvice očekivanja i ljestvice percepcije čine povezane tvrdnje. Ova pojava ukazuje na to da su posjetiteljima te tvrdnje bile najmanje važne, iz čega proizlazi i negativan jaz.

U nastavku su prikazane tvrdnje s najvećim ECOSERV jazom. 
Na temelju podataka iz tablice 6 može se zaključiti kako najveći jaz $(-2,15)$ nije direktno povezan sa samom uslugom, već se odnosi na dimenziju eko-opipljivosti „Objekti i oprema u zaštićenom području ekološki su prihvatljivi, nemaju znatan utjecaj na okoliš (vozila na struju, korištenje obnovljivim izvorima energije, recikliranje otpada....)" Analizom podataka utvrđeno je kako je glavni problem zaštićenih područja sama infrastruktura i oprema koja nije u skladu s očekivanjima posjetitelja. Stoga bi ustanove za zaštitu prirode morale više pažnje posvetiti poboljšanju navedenog kako bi se povećalo ukupno zadovoljstvo posjetitelja.

Tablica 7 prikazuje rezultate analize zadovoljstva i lojalnosti posjetitelja zaštićenih područja u Istarskoj županiji.
Iz tablice je vidljivo kako su posjetitelji zadovoljni ponudom i kvalitetom usluge koja im je pružena, što pokazuje prosječna ocjena od 5,3. Tvrdnjama „Ponovno bih posjetio/posjetila ovo zaštićeno područje” i „Preporučio/preporučila bih ovo zaštićeno područje drugima" dodijeljene su visoke prosječne ocjene 6,08 i 6,06. Takve ocjene ukazuju na to da, iako ustanove za zaštitu prirode nisu uspjele u potpunosti ispuniti očekivanja posjetitelja, posjetitelji su zadovoljni sveukupnom ponudom i uslugama te su spremni ponovno posjetiti zaštićeno područje i preporučiti ga drugima.

$\mathrm{Na}$ temelju provedene statističke analize podataka može se zaključiti kako je percipirana kvaliteta usluga u zaštićenim područjima Istarske županije visoka. Naj-

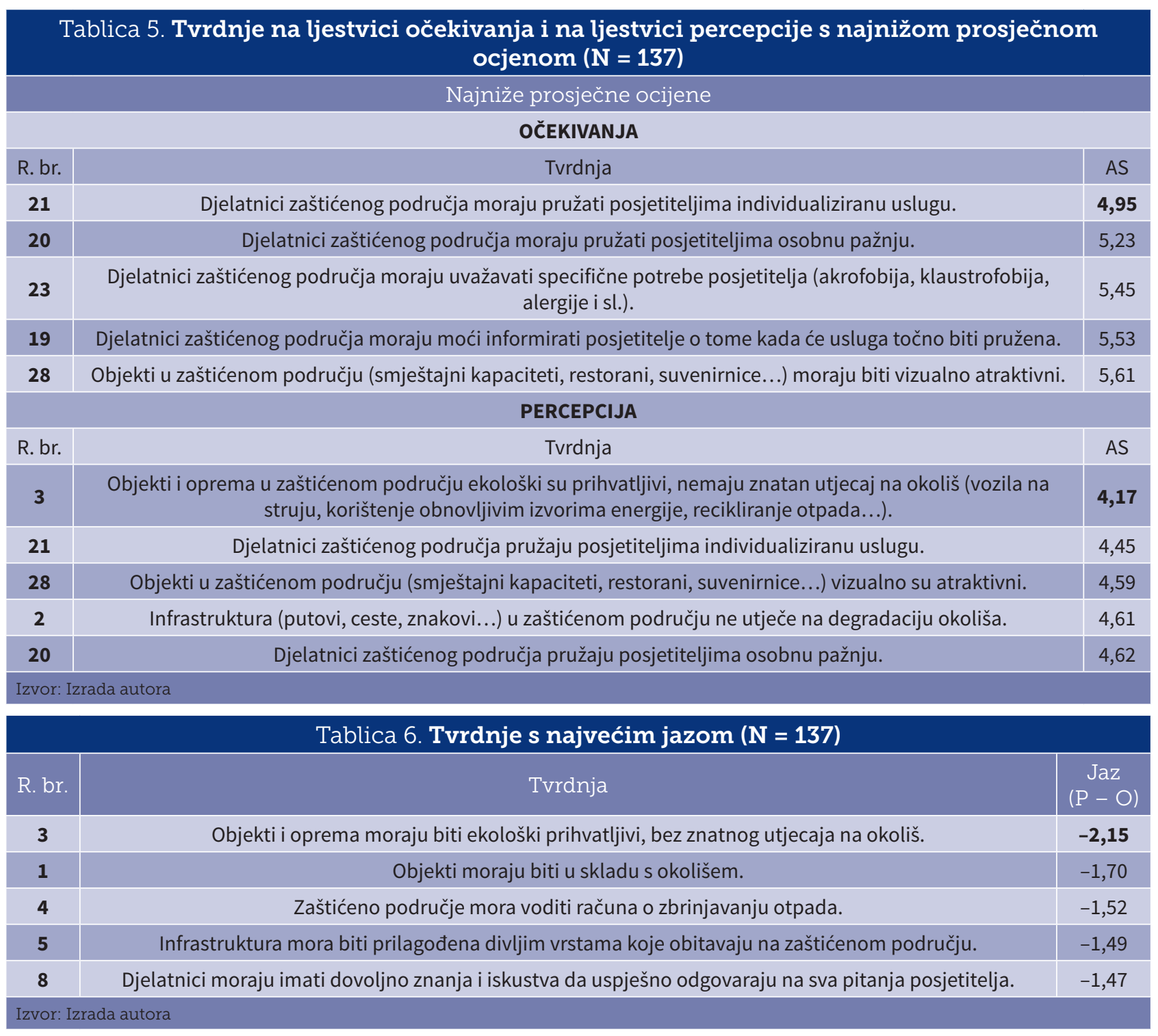


Tablica 7. Analiza zadovoljstva i lojalnosti posjetitelja zaštićenih područja $(\mathbf{N}=137)$

\begin{tabular}{|c|c|c|}
\hline R.br. & Tvrdnja & Prosječna ocjena \\
\hline $\mathbf{1}$ & ZADOVOLJSTVO & 5,30 \\
\hline $\mathbf{2}$ & Zadovoljan/zadovoljna sam sveukupnom ponudom i uslugom zaštićenog područja. & \\
\hline $\mathbf{3}$ & LOJALNOST & 6,08 \\
\hline Izvor: Izrada autora & Preporučio/preporučila bih ovo zaštićeno područje drugima. & 6,06 \\
\hline
\end{tabular}

manja ocjena percipirane kvalitete usluga dodijeljena je najvažnijoj dimenziji „eko-opipljivost” što upućuje na potrebu za poboljšanje te dimenzije.

\section{Zaključak}

Zaštićena područja jesu područja u kojima je glavni cilj zaštita biološke, geološke i krajobrazne raznolikosti. Također predstavljaju krhke oaze u kojima suvremeni čovjek pokušava pobjeći od stresa i obveza, krivo vjerujući da se u njima može povezati s prirodom u njezinu izvornom obliku. Kao takva, zaštićena područja ipak su najvažnija karika za razvoj ekoturizma. Pritom se kroz sintagmu održivog razvoja i održivosti turizma mora voditi računa kako prekomjerna posjećenost negativno djeluje na zaštićeno područje i time dovodi u pitanje ili poništava osnovnu svrhu postojanja. Koncept održivog turizma, iako i dalje antropocentrički orijentiran, mora pronaći optimalan omjer između maksimiziranja profita od posjetitelja i minimiziranja negativnog utjecaja na okoliš kako bi ustanove i posjetitelji bili zadovoljni.

Rezultati statističke analize istraživanja zadovoljstva posjetitelja zaštićenih područja u Istarskoj županiji primjenom modela ECOSERV pokazali su da je negativan jaz prisutan u svim varijablama kvalitete usluga. Takav rezultat znači da je percipirana usluga niža od očekivane, tj. da ustanove nisu ispunile očekivanja svojih posjetitelja te je u tom slučaju preporučljivo da ustanova intervenira u cilju poboljšanja. Najmanjom prosječnom ocjenom ocijenjeni su materijalni čimbenici, oprema i infrastruktura. Pretpostavka je da ako dođe do njihove izmjene ili poboljšanja u što kraćem vremenu, doći će i do podizanja kvalitete usluga.
Zaštićena područja uglavnom posjećuju mladi ljudi u dobi do 35 godina (70\% ispitanika) koji su zaposleni ili još studiraju, a glavni je motiv posjeta zaštićenom području odmor i opuštanje u prirodi. Jednostrukom regresijskom analizom utvrđeno je kako zadovoljstvo posjetitelja direktno utječe na njihovu lojalnost, što potvrđuje i podatak kako je $67 \%$ ispitanika posjetilo zaštićeno područje više od dva puta.

Domaća i strana stručna literatura koja se bavi istraživanjem kvalitete usluga isključivo u zaštićenim područjima vrlo je oskudna. Iz tog razloga ovo istraživanje može poslužiti kao vrlo dobra podloga budućim istraživanjima tog tipa. Ograničenja ovog istraživanja očituju se u tome što su ispitanici većinom bili samo lokalni posjetitelji, i to uglavnom skupine (studenti i/ili rekreativci) koji su ciljano posjetili određeno zaštićeno područje. Potrebna je primjena istog anketnog upitnika kako bi budući rezultati bili usporedivi.

Kako bi se kontinuirano unaprjeđivala kvaliteta i time povećalo zadovoljstvo posjetitelja, a indirektno usmjeravalo uprave na poštivanje gornjih granica prihvata posjetitelja pojedine destinacije, potrebno je provoditi istraživanja kroz cijelu godinu na većem broju zaštićenih područja Istarske županije, ali i regionalno i svakako na većem slučajnom uzorku.

\section{Referencije}



1. Crompton JL, Love LL. The predictive validity of alternative approaches to evaluating quality of a festival. Journal of Travel Research, 1995, 34(1): 11-24. Dostupno na: https://doi.org/10.1177\%2F004728759503400102

2. Cronin JJ, Taylor A. Measuring service quality: A reexamination and extension. Journal of Marketing, 1992, 
56(3), 55-68. Dostupno na: https://doi.org/10.1177\% 2F002224299205600304

3. Gotlieb JB, Grewal D, Brown SW. Consumer satisfaction and perceived quality: Complementary or divergent constructs? Journal of Applied Psychology, 1994, 79(6): 875-885.

4. Grönroos C. A service quality model and it's marketing implications. European Journual of Marketing, 1984, 18(4): 36-44. Dostupno na: https://doi.org/10.1108/ EUM0000000004784 (pristupljeno 11.3.2019.).

5. Gundersen MG, Heide M, Olsson UH. Hotel Guest satisfaction among Business Travellers: What Are the Important Factors?, The Cornell Hotel and Restaurant Administration Quarterly. 1996, 37(2): 72-81. Dostupno na: https://doi.org/1 0.1177\%2F001088049603700222 (pristupljeno 11.3.2019.).

6. Khan M. ECOSERV: Ecotourists quality expectations. Annals of Tourism Research, 2003, 30(1): 109-124. Dostupno na: https://doi.org/10.1016/S0160-7383(02)00032-4 (pristupljeno 11.3.2019.).

7. Kosović M. Modeliranje upravljanja zaštićenim područjima na primjeru upravljanja „Park šume Marjan”, Magistarski rad. Split: Sveučilište u Splitu. 2006.

8. Krpina V. Analiza odnosa između posjetitelja i zaštićenih područja prirode u Zadarskoj županiji. Šumarski list, 2015, 139(11-12): 535-551. Dostupno na: https://hrcak. srce.hr/157018 (pristupljeno 11.3.2019.).

9. Ladhari R. Alternative measures of service quality: a review. Managing Service Quality, . 2009, 18(1): 65-86. Dostupno na: https://doi.org/10.1108/09604520810842849

10. Lee J, Graefe AR, Burns RC. Service quality, satisfaction, and behavioural intention among forest visitors. Journal of Travel \& Tourism Marketing, 2004, 17(1): 73-82. Dostupno na: https:// doi.org/10.1300/J073v17n01_05 (pristupljeno 11.3.2019.).

11. Liljander V, Strandvik T. Emotions in service satisfaction. International journal of service industry management, 1997, 8(2):148-169. Dostupno na: https://pdfs.semanticscholar. org/c2e3/900182191fcfbfe9ad2baa69567e2540170f.pdf

12. Mackay KJ, Crompton JL. Measuring the quality of recreation services. Journal of Park and Recreation Administration, 1990, 8 (3):47-56. Dostupno na: http:// agrilifecdn.tamu.edu/cromptonrpts/files/2011/06/FullText104.pdf (pristupljeno 11.3.2019.).

13. Manning RE, Lime DW. Defining and managing the quality of wilderness recreation experiences. In Wilderness science in a time of change conference, 2000, 4: 13-52. Dostupno na: https://www.wilderness.net/library/documents/manning_4-4.pdf (pristupljeno 11.3.2019.).

14. Marković S. Mjerenje kvalitete usluga u hotelskoj industriji - atributivni pristup. Doktorska disertacija. Rijeka: Sveučilište u Rijeci, 2003.

15. Markus T. Ekološka etika-razvoj, mogućnosti, ograničenja. Socijalna ekologija: časopis za ekološku misao i sociologijska istraživanja okoline, 2004, 13(1): 1-23. Dostupno na: https://hrcak.srce.hr/29016 (pristupljeno 11.3.2019.).

16. Marušić Z, Tomljenović R, Klarić Z. Attitudes and expenditures of visitors in national and nature parks in Croatia. Tomas National and Nature Parks 2006. Zagreb: Institut za turizam, 2007.
17. O'Neill MA, Riscinto-Kozub KA, van Hyfte M. Defining visitor satisfaction in the context of camping oriented nature-based tourism - the driving force of quality!. Journal of Vacation Marketing, 2010, 16(2): 141-156. Dostupno na: https://doi. org/10.1177\%2F1356766710364541 (pristupljeno 11.3.2019.).

18. Oliver RL. Measurement and Evaluation of Satisfaction Process in Retail Setting. Journal of Retailing, 1981, 57(3), 25-48. Dostupno na: https://psycnet.apa.org/record/1984-10995-001 (pristupljeno 11.3.2019.).

19. Ostrowski PL, O'Brien TV, Gordon GL. Service quality and customer loyalty in the commercial airline industry, Journal of Marketing, 1993, 22 (2):16-24. Dostupno na: https://doi.org/10. 1177\%2F004728759303200203 (pristupljeno 11.3.2019.).

20. Parasuraman A, Zeithaml VA, Berry L. A conceptual model of service quality and its implications for future research. Journal of Marketing, 1985, 49(Fall): 41-50. Dostupno na: https://doi.or g/10.1177\%2F002224298504900403

21. Parasuraman A. SERVQUAL: A Multiple-Item Scale for Measuring Consumer Perceptions of Service Quality. Journal of Retailing, 1988, 64 (1):12-40. Dostupno na: https://search.proquest. com/openview/7d007e04d78261295e5524f15bef6837/1?pqorigsite=gscholar\&cbl=41988 (pristupljeno 11.3.2019.).

22. Parasuraman A. Customer service in business-to-business markets: An agenda for research. Journal of business and industrial marketing, 1998, 13(4/5): 309-321. Dostupno na: https://doi.org/10.1108/08858629810226636 (pristupljeno 11.3.2019.)

23. Rivera MA, Croes R. Ecotourists' loyalty: Will they tell about the destination or will they return? Journal of Ecotourism, 2010, 9(2): 85-103. Dostupno na: https://doi. org/10.1080/14724040902795964 (pristupljeno 11.3.2019.).

24. Sureshcander GS, Rajender C, Anantharman RN. The Relationship between management's perception of total quality service and customer's perception of service quality. Total Quality Management, 2002, 13(1): 69-88. Dostupno na: https://doi.org/10.1080/09544120120098573 (pristupljeno 11.3.2019.).

25. Sureshchandar GS, Rajendran C, Kamalanabhan TJ. Customer perceptions of service quality: a critique. Total Quality Management, 2001, 12(1):111-124. Dostupno na: https://doi. org/10.1080/09544120020010138 (pristupljeno 11.3.2019.).

26. Tian-Cole S, Crompton JL,Wilson VL. An empirical investigation of the relationshipsbetween service quality, satisfaction and behavioural intentions among visitors to a wildlife refuge. Journal of Leisure Research, 2002, 34(1): 1-24. Dostupno na: https://doi.org/10.1080/00222216.2 002.11949957 (pristupljeno 11.3.2019.).

27. Tian-Cole S, Cromption J. A conceptualization of the relationships between service quality and visitor satisfaction, and their links to destination selection. Leisure studies, 2003, 22(1): 65-80. Dostupno na: https://doi. org/10.1080/02614360306572 (pristupljeno 11.3.2019.).

28. Zabkar V, Brenčič M, Dmitrović T. Modelling perceived quality, visitor satisfaction and behavioural intentions at the destination level. Tourism Management, 2010, 31(4): 537-546. Dostupno na: https://doi.org/10.1016/j. 


\section{VISITOR'S SATISFACTION RESEARCH OF ISTRIAN COUNTY'S PROTECTED AREAS}

1 Suzana Marković

1 University of Rijeka, Faculty of Tourism and Hospitality Management, Opatija, Hrvatska
Sample and method: Research was conducted on a sample of 137 visitors to the following protected nature areas: Brijuni National Park, Učka Nature Park, Šijana Forest Park and Kamenjak Nature Park. Only domestic visitors participated in the survey.

Results: The results of descriptive statistical analysis indicate that a gap exists between expected and perceived service quality, meaning that the institutions failed to meet the expectations of their visitors, even though visitors gave high average scores to service quality in nature parks.
Introduction: Protected nature areas are fragile oases where people can connect with nature in its authentic form. Their main aim is to ensure the conservation of biological, geological and landscape diversity. Because of ever greater socio-economic development, with surging industrialisation, traffic and urbanisation, only through the synergistic action of sustainable tourism and nature conservation will it be possible to lessen the desire for profit which is driving over-building and over-visitation that can adversely impact protected areas (through habitat degradation, pollution etc.), thus calling into question the primary purpose of their existence.

This paper aims to study and analyse the attitudes of visitors to the protected areas of Istria County on service quality. It will also analyse visitor satisfaction and loyalty, and expectations and perceptions, and calculate the ECOSERV gap, for which purpose the ECOSERV scale has been adapted (Khan, 2003). The questionnaire consists of six dimensions (eco-tangibles, assurance, reliability, responsiveness, communicativeness, tangibles) and 29 statements as well as questions relating to the sociodemographic profile of respondents (age, gender, education, job, reasons to travel, number of visits).
Keywords: visitor satisfaction, service quality, ECOSERV, protected nature areas, statistical analysis 